neofilolog

Czasopismo Polskiego Towarzystwa Neofilologicznego

ISSN 1429-2173, 2019, NR 52/2, 411-418

http://dx.doi.org/10.14746/n.2019.52.2.13

http://poltowneo.org/

Anna Jaroszewska

Uniwersytet Warszawski

https://orcid.org/0000-0003-2788-593X

a.jaroszewska@uw.edu.pl

\title{
SUBIEKTYWNA REFLEKSJA GLOTTODYDAKTYKA PO LEKTURZE KSIAZZKII WERONIKI WILCZYŃSKIEJ, MACIEJA MACKIEWICZA I JAROSŁAWA KRAJKI KOMUNIKACJA INTERKULTUROWA. WPROWADZENIE
}

WYDAWNICTWO NAUKOWE UAM, POZNAŃ 2019, SS. 685

\begin{abstract}
Keywords: intercultural communication
\end{abstract}
Słowa kluczowe: komunikacja interkulturowa

Już dziesiątki lat osobistych, zupełnie przypadkowych lub świadomie inspirowanych spotkań i interakcji z przedstawicielami innych języków i kultur; w kraju i zagranicą, w zróżnicowanych kontekstach sytuacyjnych. Poznane z autopsji, w toku obserwacji bądź z relacji osób trzecich i literatury przedmiotu zjawiska psychospołeczne, takie jak: kultura i kulturowa obcość oraz inność, bariera komunikacyjna, lęk przed nieznanym, zagubienie i wyobcowanie, różnej kategorii stereotypy i rodzące się na tym gruncie uprzedzenia, nietolerancja, dyskryminacja, agresja i międzykulturowy konflikt. W opozycji do powyższego: zwykła ludzka ciekawość, także fascynacja, otwartość, dążenie do zrozumienia, tolerancja i akceptacja, poczucie bezpieczeństwa, przynależności lub po prostu naturalnej inności, w końcu międzykulturowy dialog - jako fundament współistnienia i współpracy w różnych sytuacjach dnia codziennego, w sferze zawodowej oraz bliskich relacji prowadzących do długoletniej przyjaźni. Przeszło dwudziestoletnia praktyka wychowawcy i nauczyciela języków obcych realizowana w grupach uczniów zróżnicowanych pod względem pochodzenia, 
wieku, mobilności, poglądów i kompetencji komunikacyjnych, w różnych placówkach oświatowych, w tym na poziomie kształcenia akademickiego wśród studentów - przyszłych nauczycieli języka niemieckiego. Do tego aktywne uczestnictwo w gremiach naukowych, sprzyjające wymianie zdań i doświadczeń na temat międzyludzkiej komunikacji, wielojęzyczności, ale też nierozerwalnie powiązanych z nimi wielo- i międzykulturowości. Liczne autorskie teksty i materiały nauczania poświęcone tej problematyce, dziesiątki zaopiniowanych podręczników szkolnych. Czy czyni mnie to przygotowaną do międzykulturowych interakcji, do życia w kulturowym tyglu, rozwiązywania związanych z tym problemów, w końcu kształcenia innych, jak problemy te rozwiązywać, bo przecież nauka języków obcych nie ogranicza się li tylko do przekazywania wiedzy językowej? Po części zapewne tak, ale...

To przygotowanie do życia przekraczające próg zawodowego nowicjatu, właściwego młodym adeptom nauczycielskiej profesji bądź początkującym badaczom ludzkich języków i kultur oraz metod ich eksploracji, analizy i poznania. Jednak wciąż niepełne i z pewnością niewystarczające, wymagające kolejnych lat wytężonej pracy i nauki, licznych własnych, ale też cudzych prób i błędów, porażek i sukcesów, by jeszcze lepiej poznać i zrozumieć człowieka, istotę zaiste społeczną, która, żeby przetrwać, jak również osiągnąć pełnię szczęścia, jest zmuszona skutecznie komunikować z innymi ludźmi. Komunikacja ta coraz częściej musi się odbywać z pominięciem dobrodziejstw mowy ojczystej - w językach obcych, zarówno wśród swoich, jak i w gronie obcych, ze wszystkimi tego społecznokulturowymi konsekwencjami, których nie można przecież bagatelizować. $W$ dobie nadzwyczaj dynamicznych zmian geopolitycznych, kulturowych, społecznych, gospodarczych czy technologicznych, coraz śmielej sięgających najdalszych zakątków globu ziemskiego, efektywna komunikacja międzykulturowa stała się wyzwaniem ogólnospołecznym. Zdolność pokonania kulturowych i komunikacyjnych barier, które od zarania ludzkości w naturalny sposób dzielą ludzi na swoich i obcych, jest dziś wyższym dobrem stanowiącym poważny $\mathrm{i}$ - co istotne - bezpieczny oręż w walce o lepsze jutro, o cywilizacyjny rozwój i pokój na Ziemi - tak w skali globalnej, jak i w granicach naszych małych ojczyzn, które dawno już przestały być monolingwalne, a tym bardziej monokulturowe. $Z$ jednej strony otrzymaliśmy szansę i nieograniczone wręcz możliwości wniknięcia w tę nową i wciąż pełną tajemnic, a przez to fascynującą rzeczywistość. Jest to współcześnie przywilej powszechny, a nie, jak niegdyś, dedykowany wybranym grupom czy nawet jednostkom. $Z$ drugiej strony w obliczu tych przemian wszyscy napotykamy na realne trudności i zagrożenia, których nie możemy nie zauważać, z którymi również musimy się zmierzyć. Pomimo rozwoju i upowszechnienia szeroko pojętej oświaty, redefiniowania i prób unifikacji zbioru praw i wolności człowieka, mimo otwarcia 
granic oraz rosnącej intensyfikacji spotkań i głębokich interakcji na kulturowym pograniczu, w konfrontacji z innością i obcością nadal bardzo często brakuje nam cierpliwości, motywacji, inspiracji, gotowości, niekiedy podstawowej wiedzy. Odnosi się to zarówno do spraw ważnych, jak i błahych, publicznych i prywatnych. Dotyczy prawdopodobnie większości z nas, niezależnie od wykonywanego zawodu, narodowości, koloru skóry, wyznania, światopoglądu itd. Czy można temu zaradzić w gonitwie myśli, terminów i wydarzeń, w natłoku zawodowych obowiązków i rodzinnych powinności, wobec braku czasu, ale też napływu często niespójnych i trudnych do zweryfikowania informacji? Dla wielu z nas jest to zadanie wykonalne, choć niewątpliwie wymagające pełnego zaangażowania i uwagi. Gdzie jednak szukać wsparcia, podpowiedzi, być może sprawdzonych rozwiązań, by swą niewiedzę uzupełnić, a mylne pojęcie o innych kulturach sprostować? Bez wyczerpującego przewodnika trudno nam będzie w międzykulturowej rzeczywistości w pełni zaistnieć, jeszcze trudniej będzie odpowiedzialnie i bez najmniejszych wątpliwości w tym zakresie kształcić młode pokolenia, np. nauczycieli języków obcych, choć nie tylko. Szczególnie pomocna w realizacji tego przedsięwzięcia może okazać się najnowsza książka Weroniki Wilczyńskiej, Macieja Mackiewicza i Jarosława Krajki, wybitnych polskich neofilologów, którzy - mimo różnych specjalizacji zawodowych - postanowili wspólnie wypowiedzieć się na wyjątkowo rozległy i złożony temat, jakim jest właśnie komunikacja międzykulturowa.

Przywołana książka, a właściwie bardzo obszerna, bo licząca 685 stron, monografia naukowa, ukazała się drukiem w 2019 roku nakładem Wydawnictwa Naukowego Uniwersytetu im. Adama Mickiewicza w Poznaniu. Jej skromny tytuł: KOMUNIKACJA INTERKULTUROWA. WPROWADZENIE zdecydowanie nie oddaje ogromu zgromadzonych w niej informacji na temat tego zagadnienia, zjawiska, procesu. O tym jednak za chwilę. Na wstępie warto bowiem podkreślić znakomitą jakość wydania, która zadowoli nawet najbardziej wymagającego czytelnika. Składają się na nią: a) sztywna, wielobarwna oprawa z intrygującą ryciną "multimedialnego drzewa" autorstwa Ewy Wąsowskiej, b) poręczny format B5, c) niebudząca zastrzeżeń jakość klejenia kart, d) dobry, czytelny druk, e) tekst w doskonałym opracowaniu typograficznym Moniki Tyma, f) dopełniony kolorowymi rycinami, których obróbkę graficzną zrealizowała Agnieszka Nowicka, g) logiczny i trafny układ treści, obejmujący: wstęp, dziewięć rozdziałów, zakończenie, przebogatą bibliografię - w której zebrano ponad 450 pozycji źródłowych, wielce użyteczny słowniczek terminów, w końcu anglojęzyczne streszczenie. Poza zespołem autorów, opiekę nad całym projektem przejęli redaktorzy Roman Bąk i Dorota Borowiak, którym również należy pogratulować finalnego efektu ich pracy.

Nie sposób w tych kilku przynależnych recenzji zdaniach nawet pobieżnie zreferować treść poszczególnych rozdziałów tego dzieła. Jest to po prostu 
zbiór zbyt duży i wielowątkowy. Znacznie większy walor informacyjny będzie miało raczej przywołanie ich nazw i głównych śródtytułów:

(1) Kultura - atrybut człowieka i społeczności ludzkich (s. 17-66), a w nim:

- Człowiek, natura, kultura;

- Ujęcie obrazowe: drzewo kultury;

- Sposoby ujmowania kultury i ich funkcjonalność;

- Główne pojęcia powiqzane;

- Kultury jako przewodniki po rzeczywistości;

- Kultura a tożsamość;

- Kultura, język, społeczeństwo: ograniczoność ujęć ogólnych;

- Wspólnota jako podmiot kultury;

- Podsumowanie;

(2) Badania interkulturowe (s. 67-130), a w nim:

- Ogólna charakterystyka badań nad kultura;

- Interkulturowość jako nowe pole badawcze;

- Porównywanie kultur jako wyzwanie poznawcze i metodologiczne;

- Wspólnoty dyskursywne jako podmiot kultury;

- jednostka a kultura: ujęcie podmiotowe;

- Podsumowanie;

(3) Kontekstowe wyznaczniki relacji interkulturowych (s. 131-229), a w nim:

- Typy odrębności kulturowo-językowych;

- Stosunki językowe a regulacje prawne;

- Modelowanie relacji międzykulturowych: typologia J. Berry'ego;

- Charakterystyka współczesnych społeczeństw;

- Wielokulturowość jako zjawisko i program społeczno-polityczny;

- Dynamika tożsamości kulturowej: akulturacja i integracja;

- Podsumowanie;

(4) Symboliczna, systemowa natura języka (s. 231-316), a w nim:

- Systemowość języka - uwagi ogólne;

- Znak i jego struktura;

- Znaczenia językowo-kulturowe;

- Mentalność językowa: ujęcia współczesne;

- Kognitywne interpretacje organizacji znaczenia;

- Zjawisko dwu- i kilkujęzyczności;

- Podsumowanie;

(5) Teoretyczne podstawy komunikacji interkulturowej (s. 317-378), a w nim:

- Istota i rodzaje komunikacji interkulturowej;

- Przełom w badaniach nad komunikacja interkulturowq;

- Kolejne poszerzenia zakresów analizy komunikacji;

- Style komunikacji; 
- Style tekstowe a style intelektualne: dyskurs akademicki;

- Współczesne zagrożenia dla komunikatywności języka;

- Kompetencja interkulturowa;

- Podsumowanie;

(6) Interkulturowe relacje interpersonalne - uwarunkowania i dynamika (s. 379-444), a w nim:

- Ogólna typologia kontaktów interkulturowych;

- Postrzeganie kulturowe: od swojskości do inności;

- Postawy w relacjach interkulturowych: ujęcie psychokulturowe;

- Stereotypy i stereotypizacja;

- Filozofia dialogu (spotkania) jako podstawa relacji międzyludzkich;

- Od listy różnic kulturowych do pogłębionej interpretacji;

- Indywidualne strategie i postawy w komunikacji interkulturowej;

- Podsumowanie;

(7) Komunikacja interkulturowa w świecie nowych mediów (s. 445-518), a w nim:

- Elektroniczna komunikacja interkulturowa jako forma komunikacji masowej;

- Media elektroniczne: od starych do nowych nowych mediów (NNM);

- Wybrane gatunki oraz struktury ponadgatunkowe;

- Interakcje językowe w sieci;

- Wybrane rodzaje komunikacji 2.0;

- Negatywne zjawiska użycia nowych mediów w komunikacji interkulturowej;

- Podsumowanie;

(8) Komunikacja interkulturowa w biznesie (s. 519-572), a w nim:

- Rodzaje uczestników i miejsca relacji interkulturowych w biznesie;

- Kultury organizacyjne;

- Zarzqdzanie międzykulturowe;

- Negocjacje interkulturowe;

- Międzykulturowe aspekty reklamy;

- Podsumowanie;

(9) Edukacja interkulturowa (s. 573-647), a w nim:

- Konteksty, potrzeby, motywacje w kształceniu interkulturowym;

- Kompetencja interkulturowa: wybrane koncepcje i podejścia;

- Wspótczesna debata nad interkulturowościq;

- Edukacyjna polityka językowa UE;

- Dydaktyka interkulturowa w praktyce;

- Ewaluacja kompetencji interkulturowej;

- Podsumowanie. 
Są to rozdziały stricte teoretyczne. Każdy z nich został zwieńczony syntetycznym podsumowaniem, które dopełniono trafnymi wnioskami autorskimi. Kompozycja ta jest zrównoważona, a sposób dozowania w niej informacji umiejętny.

Warto przy tym zaznaczyć, że, mimo wysoce teoretycznego umocowania prowadzonych rozważań, pozytywnie zaskakuje mnogość obecnych na kartach pracy wyników badań empirycznych, szczegółowo opisanych epizodów badawczych lub, po prostu, sytuacji życiowych, zaczerpniętych z opublikowanej już literatury przedmiotu, mediów codziennych bądź z własnego doświadczenia autorów i/lub osób im bliskich, a dotyczących szerokiej palety kultur narodowych, etnicznych, regionalnych czy subkultur oraz właściwych im języków. Częstokroć wyróżnione w ramkach, opatrzone dodatkowym komentarzem, zobrazowane na różnego typu grafikach bądź rozpisane $w$ tabelach elementy te zostały dopełnione wyraźnie wybrzmiewającymi z wywodu wskazówkami dydaktyczno-wychowawczymi (o ile tak można powiedzieć) - te zaś przedłożono czytelnikowi w bardzo przystępnej formie, łącznie przesądzając o niezwykle pragmatycznym charakterze tej publikacji. Sama zaś teoria została wyłożona w sposób wyjątkowo klarowny i wyważony, skrupulatnie, w logicznym ciągu, bardzo dobrym i jednocześnie przyjaznym niespecjalistom stylem naukowym. Celnie wpleciono ją w zawiłości prozy życia (także jego kolorytu), nadając książce z jednej strony postać podręcznika czy wykładu akademickiego, $z$ drugiej również instruktażu, a nawet poradnika - w pozytywnym tych pojęć znaczeniu. Należy przy tym zaznaczyć, że autorzy nie uzurpują sobie prawa do prawdy/wiedzy, podkreślając wielokrotnie, iż w kwestiach tak złożonych jak relacje między ludźmi/kulturami nie można przyjąć jednej tylko perspektywy postrzegania/oceny rzeczywistości. To zresztą, w pewnym sensie, było dla nich impulsem do napisania omawianej monografii - by przedmiot swoich zainteresowań, a więc interkulturową komunikację, ukazać wielopłaszczyznowo, $z$ różnych stron i w różnych kontekstach, na ile to możliwe także szczegółowo, odnosząc się przy tym do uwarunkowań historycznych oraz wyzwań, szans i zagrożeń, jakie przynosi dynamika współczesności.

Zamieszczona w tytule monografii "uwaga”, iż jest to Wprowadzenie, zapewne niejednego czytelnika może pozytywnie zaskoczyć, bowiem jest to wprowadzenie wyjątkowo wnikliwe i jak powiedziano wcześniej - interdyscyplinarne, a przy tym przemyślane, rozważne, w końcu niebywale ciekawe. Oczywiście trudno było ukryć autorom swą językoznawczą, a ściślej: glottodydaktyczną przynależność zawodową; być może również pozazawodową, wynikającą z ich osobistych pasji i zainteresowań. W żadnym wypadku nie rzutuje to na obiektywizm prowadzonego wywodu; raczej pozytywnie intryguje. Zresztą nierozłączność kultury od języka jest tak oczywista, że trudno byłoby się dziwić nachyleniu pracy w tym kierunku. Wartość publikacji zyskuje na znaczeniu także 
przez to, że daje ona czytelnikowi nie tylko wgląd w najważniejsze nurty badawcze od lat zgłębiające tajniki ludzkich kultur i relacji między nimi (najczęściej właśnie zapoczątkowanych komunikacją werbalną) tak na gruncie humanistyki, jak i nauk społecznych, lecz pozwala również rozpoznać na tym tle wyraźnie zaakcentowaną myśl autorską - krytyczną, opiniotwórczą, konstruktywną, wybiegającą w przyszłość. Fakt, że jest to wydanie polskojęzyczne należy uznać za posunięcie jakkolwiek ujmujące autorom światowej renomy, to jednak słuszne i z punktu widzenia rozwoju nauki polskiej szczególnie ważne i pożądane. A to z takiej oto przyczyny, że dotychczas w polskim piśmiennictwie nie pojawiło się opracowanie naukowe tak aktualne, które rzeczone zagadnienie komunikacji interkulturowej ujmowałoby tak kompleksowo, z tak wielu różnych perspektyw, a nie, jak to bywa najczęściej, w wąskim ujęciu, ograniczonym specjalizacją zawodową autora, odwołującym się wyłącznie do bliskiego mu (często „wygodnego" z perspektywy własnych dociekań) nurtu badawczego, obejmującym niewielki wycinek kulturowej czy też międzykulturowej rzeczywistości.

Wykorzystane na potrzeby prowadzonych rozważań źródła internetowe i bibliograficzne są bardzo bogate, trafnie dobrane i precyzyjnie wkomponowane w treść pracy, czyniąc z niej - ograniczony, ale mimo wszystko dość obszerny i użyteczny - przewodnik po najważniejszych nurtach badawczych, dla których centralną postacią stał się człowiek, jego kultura i język - tak w ujęciu jednostkowym, jak i w wymiarze społecznym, ze szczególnym uwzględnieniem takich kluczowych kategorii, jak swojskość, obcość, inność i spajające je (jednak nie zawsze) procesy komunikacyjne. $Z$ pewnością istotnym dopełnieniem tego przewodnika jest autorski słownik przeszło 100 pojęć, które pojawiają się w pracy najczęściej, a które - zdaniem autorów (to wypada podzielić) - nazbyt często są mylnie interpretowane bądź po prostu niezrozumiane, niekiedy nawet $\mathrm{w}$ środowiskach naukowych.

Nie będzie więc nadużyciem stwierdzenie, że każdy czytelnik, który choćby w najmniejszym stopniu interesuje się kulturami (swoją, obcymi, innymi) bądź ma do czynienia z ich przedstawicielami/nosicielami, w pracy tej najpewniej odnajdzie odpowiedzi na nurtujące go pytania, cenne wskazówki, które zaspokoją jego głód poznawczy, ułatwią poruszanie się w świecie tak różnorodnym i kulturowo skomplikowanym; w gruncie rzeczy wcale nie takim oczywistym, na pewno nie czarno-białym. Jest to praca ze wszech miar naukowa, lecz przez zawarty w niej uniwersalny, niezwykle klarowny i "wielobarwny" wykład, sięgający do miejsc egzotycznych i naturalnie bliskich (m.in. Polski), wśród szerokiego grona jej adresatów, można - poza przedstawicielami świata nauki i środowiskiem akademickim, w tym studentami różnych kierunków (zwłaszcza neofilologicznych) - wymienić także: nauczycieli (nie tylko języków obcych), animatorów kultury, kulturowych mediatorów, polityków i zawodowych 
dyplomatów, przedstawicieli międzynarodowego biznesu, zwłaszcza negocjatorów, pracowników agencji medialnych i reklamowych, w końcu nas samych, nie zawsze specjalistów, często zupełnych laików, którzy we współczesnym świecie niemal codziennie są konfrontowani z kulturową innością. Warto, by możliwie najpełniej wykorzystać potencjał tych spotkań, by nie zasadzały się one na nieaktywnym „byciu obok siebie”, lecz przyjmowały postać rzeczywistego dialogu, przynoszącego obopólne korzyści nie tylko w sferze materialnej, ale i w wymiarze duchowym (w rozumieniu: ubogacania kultury-w-nas).

Reasumując, KOMUNIKACJA INTERKULTUROWA. WPROWADZENIE autorstwa Weroniki Wilczyńskiej, Macieja Mackiewicza i Jarosława Krajki to projekt wyróżniający się na tle innych publikacji naukowych poświęconych nakreślonemu w tytule zagadnieniu. Od plemion pierwotnych i przekazu słownego do "nowych" nowych mediów i cyberkodów przyszłości, od ujęć klasycznych człowieka i jego kultury po najnowsze badania interdyscyplinarne społeczności świata wirtualnego, od środowiska rodzinnego z okresu dzieciństwa do życia zawodowego i świata wielkiego biznesu, od myśli i monologu, przez stereotypy do wielostronnych negocjacji, od zapomnianych regionaliów po świat mediów, reklamy i kultury globalne, od Europy Zachodniej, przez Daleki Wschód do obu Ameryk i dalej, od tradycji chrześcijaństwa po prawidła koraniczne islamu, od spraw błahych, jak zakup suweniru na arabskim straganie, po pamięć historyczną i dumę narodową Polaków, od monokultur, przez ich różnorodność do interkulturowej komunikacji w takie i wiele innych tajników ludzkiego jestestwa, z którymi kultura i interkulturowa komunikacja są nierozerwalnie powiązane, wprowadzić może czytelnika omawiana monografia. Jest to pozycja szczególnie wartościowa i godna polecenia. Jej lektura była dla mnie intelektualną ucztą.

\section{BIBLIOGRAFIA}

Wilczyńska W., Mackiewicz M., Krajka J. (2019), Komunikacja interkulturowa. Wprowadzenie. Poznań: Wydawnictwo Naukowe UAM. 